\title{
New, Rare and Constant Habitats for Endangered Aquatic Plant Communities: The Importance of Microhabitats for Global biodiversity
}

\author{
Krzysztof Spałek ${ }^{1}$ (1) and Jarosław Proćków ${ }^{2, *(1)}$ \\ 1 Department of Botany, Institute of Biology, University of Opole, Oleska 22, 45-052 Opole, Poland; \\ kspalek@uni.opole.pl \\ 2 Department of Plant Biology, Institute of Biology, Wrocław University of Environmental and Life Sciences, \\ Kożuchowska 5b, 51-631 Wrocław, Poland \\ * Correspondence: jaroslaw.prockow@upwr.edu.pl
}

Received: 10 May 2019; Accepted: 17 June 2019; Published: 20 June 2019

\begin{abstract}
Natural water reservoirs are very valuable floristic sites, with springs particularly important for the preservation of floral biodiversity. This paper presents, as a case study, a community of water plants that is new to limnocrene karst springs in Europe: Potametum alpini (Potametea), found in Poland. The paper provides the floristic composition and ecological requirements of this plant association, which is rare and endangered in Europe. According to our knowledge, the habitat data presented here are unique as they are published for the first time for this plant community, and thus it is currently not possible to compare them with data from other authors. Our study confirms the importance of rare microhabitats for global biodiversity. Research on as yet unknown physical and chemical factors limiting the range and development of patches of different plant associations should be conducted intensively, because plant communities, including rare, endangered and protected examples, are an important element of biodiversity at both continental and local scales. All the issues discussed in the paper (rare microhabitats, endangered aquatic plant communities, global biodiversity) are important because they are related to the conservation and management of inland waters.
\end{abstract}

Keywords: global biodiversity; karst springs; microhabitats; rare habitats; rare plant communities

\section{Introduction}

Natural water reservoirs are very valuable floristic sites, with karst springs particularly important for the preservation of floral biodiversity (e.g., [1-3]). Physical and chemical properties of the substratum, its quality, as well as the general mineralization and physical properties of the water are the main factors influencing the proper development of aquatic plant communities. Although each plant community and each species in each community have their own habitat preferences, the selection of a habitat by a species is one of the least known ecological processes [4]. It is generally assumed that the choice of habitat by a plant species depends mainly on the ecological amplitude of a plant community. It therefore seems desirable to study ecosystems at the level of microhabitats, in order to identify factors that limit the development or range of plant communities. Given that microhabitat quality, especially of those in aquatic environments, changes easily under strong human pressure, it can be assumed that in most cases the factors limiting the occurrence of certain species include heavier pollution, a change in the chemical content of the water, lower/higher $\mathrm{pH}$, higher water salinity, less dissolved oxygen, more nutrients in the water, or, simply, water eutrophication.

Potametum alpini Podbielkowski 1967, as a new plant association, in phytosociological terms [5,6], was first described from drainage ditches in the Warsaw area of Poland [7]. Patches of this association 
occur in various types of cool, transparent, mesotrophic standing and slow-flowing waters on sandy or muddy substrata, including oxbow lakes, ponds, lakes and ditches [7-9]. Thus far, two subassociations of Potametum alpini have been described: P. alpini typicum and P. alpini potametosum (the latter with the participation of Potamogeton natans L.) $[9,10]$. However, according to some authors, Potamogeton alpinus Balb. is a characteristic species of the Potametum filiformis association [11-14]. A plant community dominated by P. alpinus has also been described, i.e., not at the rank of a plant association, but only at the rank of the plant community with the participation/predominance of this species [15-17]. The Potametum alpini association is listed among endangered plant communities in Europe (e.g., $[8,9,13,17-31])$.

The main goal of this paper was to analyze the importance of rare microhabitats for global biodiversity. A case study is presented of an endangered water plant community, Potametum alpini (Potametea), and a rare habitat of a limnocrene karst spring. Subsequently, the ecological requirements (new parameters found) of this association should be compared with data collected by other authors at other localities to check the ecological scale of Potametum alpini and to establish its optimal habitat conditions that is important from a biological conservation point of view.

\section{Methods}

Fieldwork was conducted during growth seasons in 2008-2015. Patches of Potametum alpini community were studied using the method of the Zurich-Montpellier School of Phytosociology [5], with phytosociological nomenclature based on Oberdorfer [6] and species names of vascular plants according to The Plant List 1.1 [32]. Basic assessment of habitat physical and chemical properties was carried out during the fieldwork. Water $\mathrm{pH}$ was measured in the spring at depths of $0-20$ and $20-40 \mathrm{~cm}$, and in the zone of the spring outflow at $0-20 \mathrm{~cm}$. Measurements of water conductivity, temperature and $\mathrm{O}_{2}$ content were taken at a depth of $0-20 \mathrm{~cm}$ at the spring and at the zone of its outflow with an Elmetron CX-401 multipurpose measuring device. Samples of water at 0-20 cm and of bottom sediments were collected from both the limnocrene spring and its outflow zone. Laboratory tests consisted of the following: Analysis of water, including measurement of $\mathrm{CO}_{2}$ content $\left[\mathrm{mg} / \mathrm{dm}^{3}\right]$; general alkalinity (measured using titration); $\mathrm{SO}_{4}{ }^{2-}$ content $\left[\mathrm{mg} / \mathrm{dm}^{3}\right]$ (measured using the turbidimetric method); $\mathrm{NO}_{3}, \mathrm{Cl}^{-}, \mathrm{NH}_{4}{ }^{+}$, and $\mathrm{PO}_{4}{ }^{3-}$ contents $\left[\mathrm{mg} / \mathrm{dm}^{3}\right]$ (measured using the colorimetric method with a Slandi spectrophotometer); and analysis of bottom sediments, including the determination of water extract $\mathrm{pH}$ (measured using the potentiometric method employed in soil sciences) and $\mathrm{CaCO}_{3}$ content $\left[\mathrm{mg} / \mathrm{dm}^{3}\right]$ (measured using the pressure calicimeter method).

\section{Results}

For the first time, Potametum alpini phytocoenoses were found in a limnocrene karst spring with an area of approximately 0.5 ha near the town of Krapkowice in southwestern Poland (Figures 1 and 2). Patches of this association occupy small areas, usually between five to $50 \mathrm{~m}^{2}$. In most patches the community is characterized by a single-layered and, less frequently, a double-layered structure. The submerged layer is dominated by Potamogeton alpinus (Figure 3, Table 1). These patches should be classified as Potametum alpini typicum subassociation $[9,10]$. Most common are patches that are highly depleted from a floristic point of view; two to six (on average four) taxa were recorded in these relevés. In total, seven plant species were recorded in the patches of the community analyzed. 


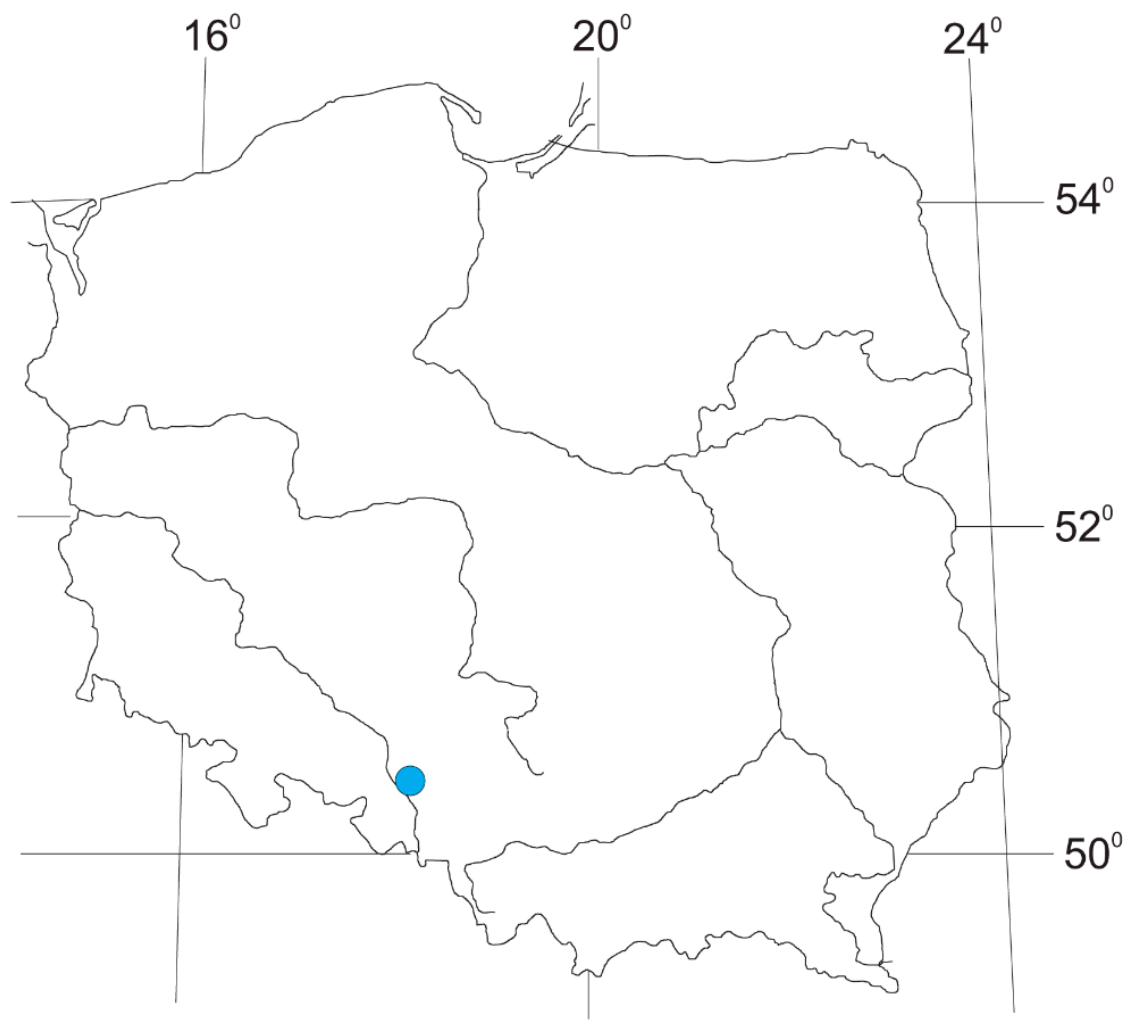

Figure 1. Locality of Potametum alpini Podbielkowski 1967 in the limnocrene karst spring in Poland.

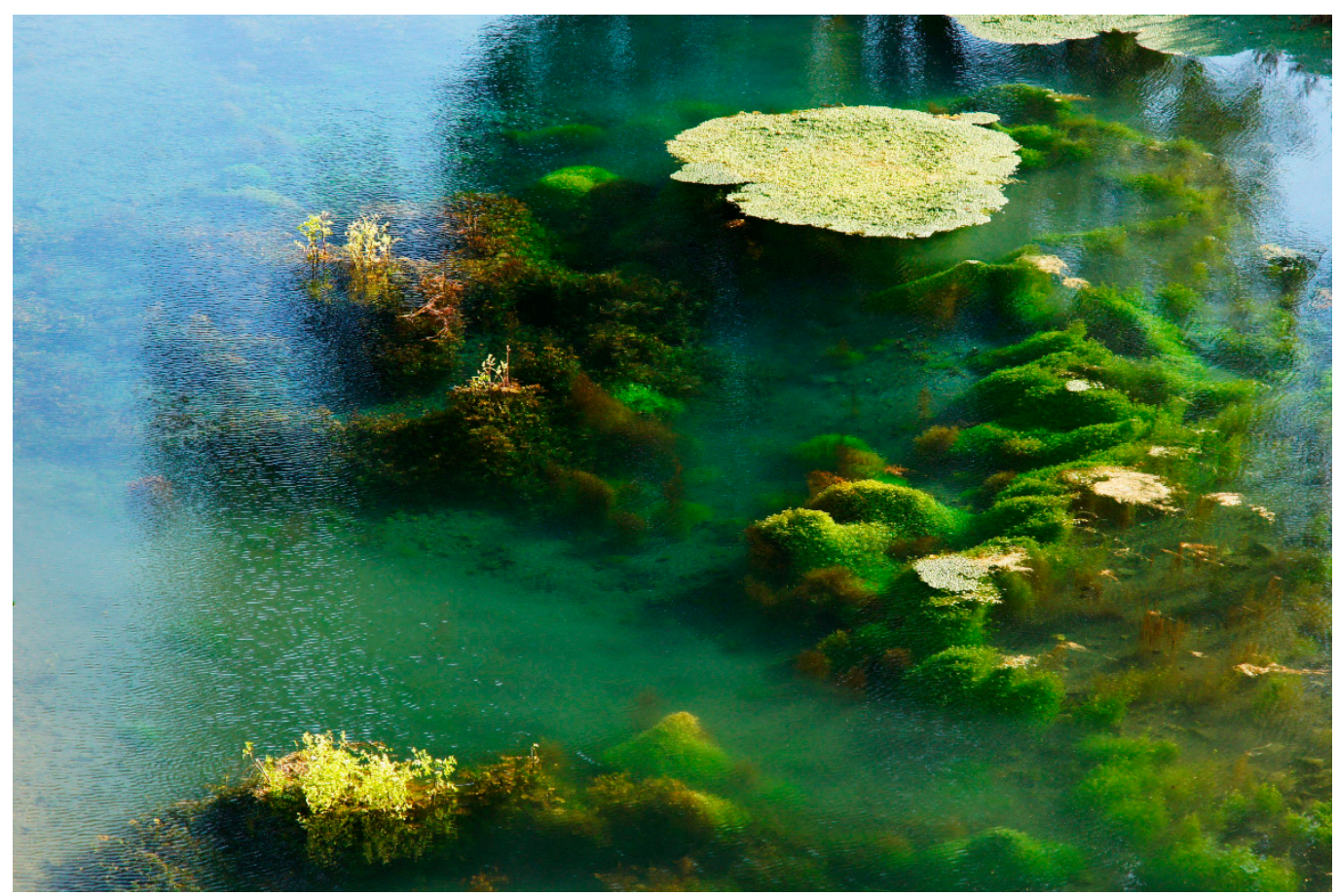

Figure 2. Potametum alpini in the limnocrene karst spring in Poland. 


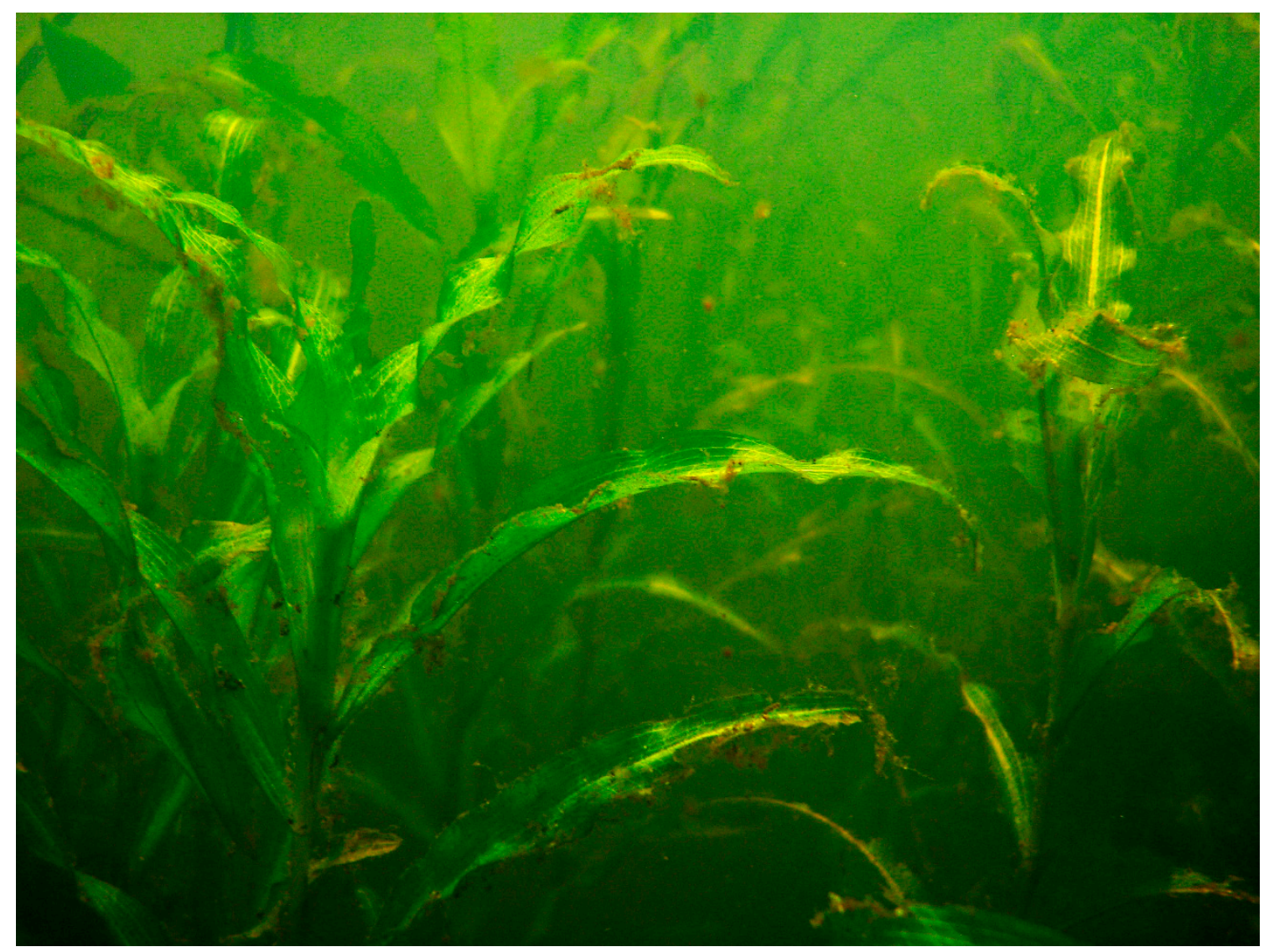

Figure 3. The limnocrene karst spring in Poland with Potametum alpini.

Table 1. Potametum alpini Podbielkowski 1967 in the limnocrene karst spring.

\begin{tabular}{|c|c|c|c|c|c|c|c|c|c|c|}
\hline Relevé Number & 1 & 2 & 3 & 4 & 5 & 6 & 7 & 8 & 9 & 10 \\
\hline Date & $\begin{array}{l}11.08 . \\
2008\end{array}$ & $\begin{array}{l}11.08 \\
2008\end{array}$ & $\begin{array}{l}11.08 . \\
2008\end{array}$ & $\begin{array}{l}11.08 . \\
2008\end{array}$ & $\begin{array}{l}11.08 . \\
2008\end{array}$ & $\begin{array}{l}29.08 . \\
2015\end{array}$ & $\begin{array}{l}29.08 . \\
2015\end{array}$ & $\begin{array}{l}29.08 . \\
2015\end{array}$ & $\begin{array}{l}29.08 . \\
2015\end{array}$ & $\begin{array}{l}29.08 \\
2015\end{array}$ \\
\hline $\begin{array}{c}\text { Cover of herb } \\
\text { layer [\%] }\end{array}$ & 40 & 25 & 50 & 35 & 40 & 40 & 35 & 55 & 30 & 35 \\
\hline Area of relevé $\left[\mathrm{m}^{2}\right]$ & 20 & 20 & 10 & 25 & 20 & 20 & 20 & 20 & 30 & 25 \\
\hline $\begin{array}{l}\text { Number of species in } \\
\text { relevé }\end{array}$ & 4 & 4 & 5 & 4 & 5 & 3 & 5 & 4 & 5 & 5 \\
\hline $\begin{array}{l}\text { Ch. Potametum alpini } \\
\text { Potamogeton alpinus } \\
\text { Ch. Potamion }\end{array}$ & 3 & 2 & 3 & 3 & 3 & 3 & 3 & 3 & 3 & 3 \\
\hline $\begin{array}{l}\text { Elodea canadensis } \\
\text { Ch. Potametalia, Pota }\end{array}$ & netea & . & . & + & + & . & . & . & . & . \\
\hline Callitriche stagnalis & 2 & 1 & 2 & + & + & 1 & 1 & 2 & + & + \\
\hline Callitriche hamulata & 1 & 1 & 1 & + & + & + & + & . & 1 & + \\
\hline $\begin{array}{l}\text { Callitriche palustris } \\
\text { Ch. Lemnetea minoris }\end{array}$ & + & . & 1 & . & 1 & . & + & + & + & + \\
\hline Lemna minor & . & + & . & . & . & . & + & + & + & . \\
\hline Spirodela polyrrhiza & . & . & + & . & . & . & . & . & . & + \\
\hline
\end{tabular}

Explanations: Ch.-characteristic species. Braun-Blanquet scale (for species cover in the surface of relevés): $3-50-25 \%, 2-25-5 \%, 1-$ five to a dozen or so specimens, cover does not exceed $5 \%$ of the relevé surface, +—slight cover (maximum up to five specimens in the relevé). 
Potametum alpini occurs within an irregularly shaped shallow limnocrene karst spring, located in the distal part of the flood terrace of the Odra River. The zone of outflow of underground waters can be classified as of the type occurring at the edge of a valley lying in the direct zone of the flood waters [33]. Alkaline sediments ( $\mathrm{pH}$ 8.03) occur within the substratum, while sediments with a lower $\mathrm{pH}(7.73)$ occur in the spring's outflow zone towards the Odra River. The reaction of this substratum shows that the nutrients are characterized by limited mobility. Laboratory analyses revealed that the bottom sediments in the spring zone are abundant in calcium $(44,038.45 \mathrm{ppm} \mathrm{Ca} / \mathrm{kg})$, iron $(5843.50 \mathrm{ppm} \mathrm{Fe} / \mathrm{kg})$, aluminum (3400.5 ppm Al/kg) and magnesium (1138 ppm Mg/kg), with the remaining compounds found in smaller concentrations of below $1 \mathrm{~g} / \mathrm{kg}(\mathrm{K}>\mathrm{Zn}>\mathrm{Na}>\mathrm{Pb}>\mathrm{Ni}>\mathrm{Cu}>\mathrm{Cd})$. Sediments in the outflow zone towards the Odra River are characterized by lower concentrations of macroelements (Figure 4) and heavy metals (Figure 5). It is found that the waters are mineralized at a level of $750 \mathrm{mg} / \mathrm{dm}^{3}$, i.e., at a higher level than recorded during studies conducted in 1978-83 at the same site [33]. Such high mineralization and contents of sulfates, calcium and magnesium indicate that the water leaches calcites and dolomites from the substratum. The water analyzed showed a slightly alkaline reaction, with $\mathrm{pH}$ varying from 7.16 directly in the spring to 7.2 in its outflow zone. These waters were well oxygenated: the content of dissolved oxygen was relatively high, at $12.8 \mathrm{mg} \mathrm{O} / \mathrm{dm}^{3}$, in the water source, but lower in its outflow zone, at $8.27 \mathrm{mg} \mathrm{O}_{2} / \mathrm{dm}^{3}$. The water temperature in the water source (at depths of $0-20$ and $20-40 \mathrm{~cm})$ was $9.6^{\circ} \mathrm{C}$, and $9.7^{\circ} \mathrm{C}(0-20 \mathrm{~cm}$ below the water level) in the outflow zone. The literature data $[33,34]$ also suggest a relatively narrow range of changes in water temperature in the limnocrene spring, of about $1^{\circ} \mathrm{C}$, with temperatures ranging from 9.4 to $10.4{ }^{\circ} \mathrm{C}$.

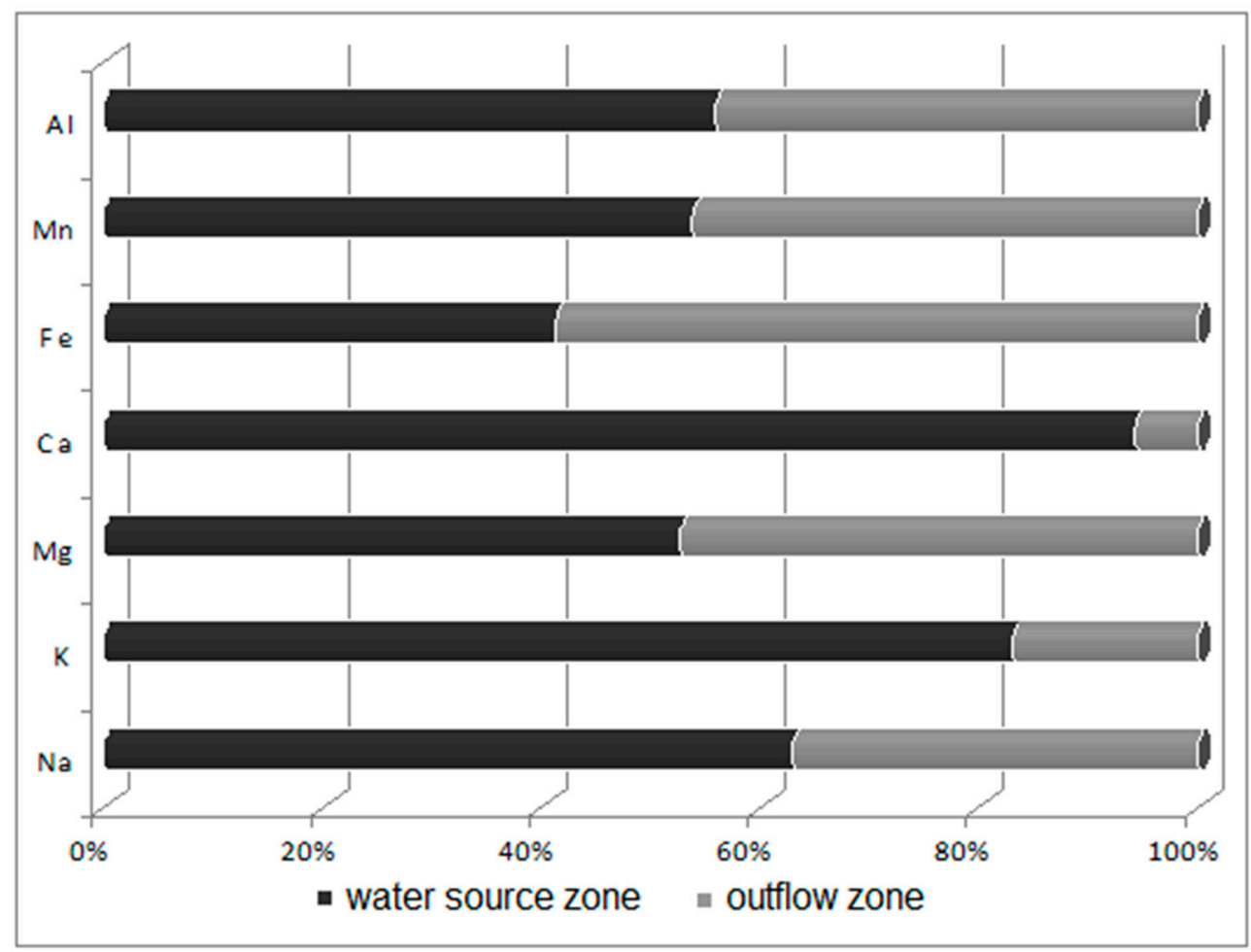

Figure 4. Ratio of sediment macroelement concentrations in the water source zone to those in the outflow zone. 


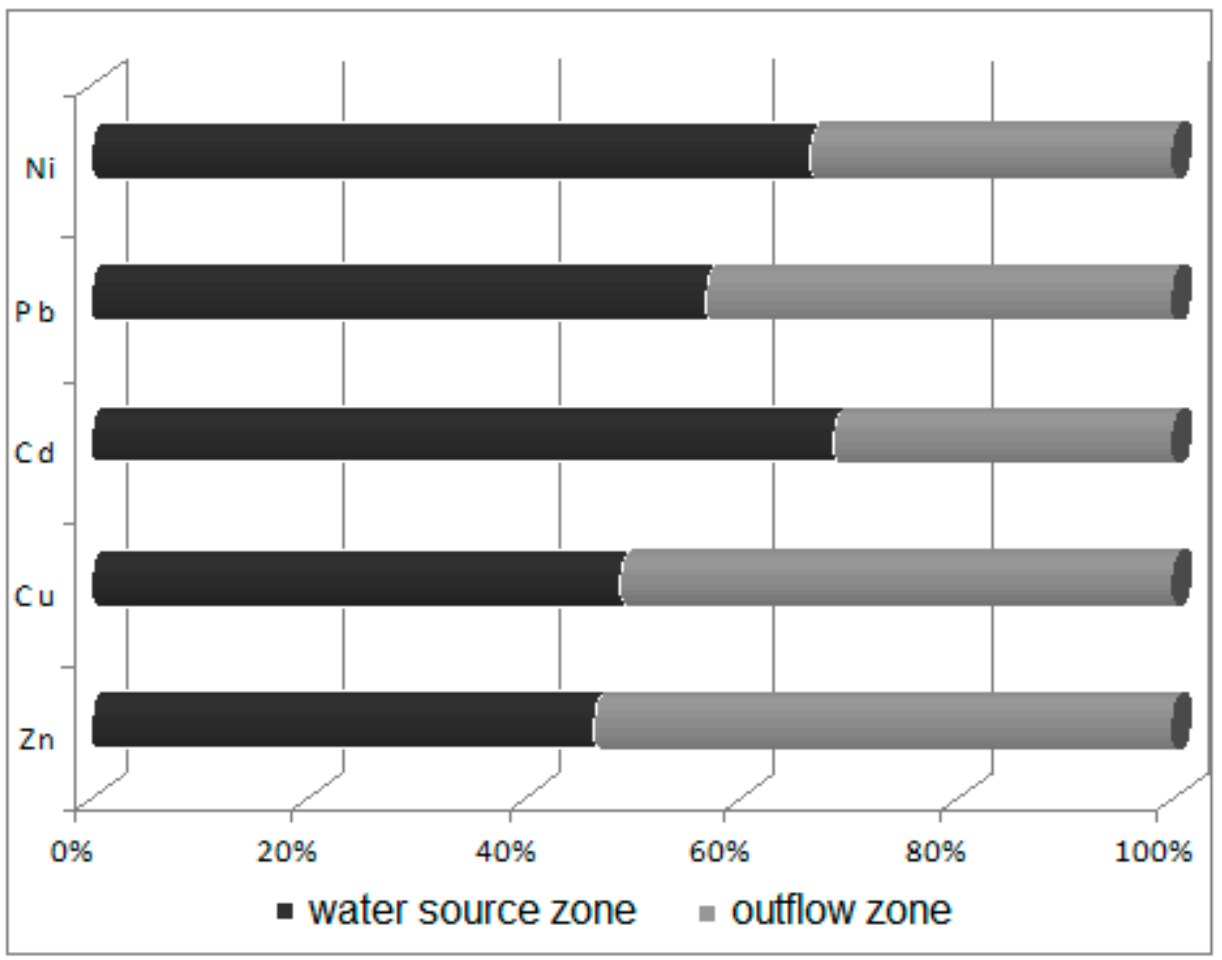

Figure 5. Ratio of sediment heavy metals concentrations in the water source zone to those in the outflow zone.

Water in the limnocrene karst spring where Potametum alpini occurred is characterized by medium-level mineralization but is also rich in dissolved compounds, containing significant concentrations of macroelements, especially of calcium $\left(93.85 \mathrm{mg} \mathrm{Ca} / \mathrm{dm}^{3}\right)$, magnesium $(19.41 \mathrm{mg}$ $\left.\mathrm{Mg} / \mathrm{dm}^{3}\right)$, sodium $\left(8.01 \mathrm{mg} \mathrm{Na} / \mathrm{dm}^{3}\right)$ and potassium $\left(1.24 \mathrm{mg} \mathrm{K} / \mathrm{dm}^{3}\right)$. The remaining elements, such as aluminum $\left(0.25 \mathrm{mg} \mathrm{Al} / \mathrm{dm}^{3}\right)$, iron $\left(0.02 \mathrm{mg} \mathrm{Fe} / \mathrm{dm}^{3}\right)$, copper $\left(0.015 \mathrm{Cu} \mu \mathrm{g} / \mathrm{dm}^{3}\right)$, zinc $(0.002 \mu \mathrm{g}$ $\left.\mathrm{Zn} / \mathrm{dm}^{3}\right)$, lead $\left(0.0014 \mu \mathrm{g} \mathrm{Pb} / \mathrm{dm}^{3}\right)$, nickel $\left(0.0011 \mu \mathrm{g} \mathrm{Ni} / \mathrm{dm}^{3}\right)$ and cadmium $\left(0.0003 \mu \mathrm{g} \mathrm{Cd} / \mathrm{dm}^{3}\right)$, occur in trace quantities (Table 2). The analysis showed that the outflowing water is similar in chemical composition to the water source (Figure 6), but is slightly more enriched in nutrients, namely nitrates (from 34.1 to $34.48 \mathrm{mg} \mathrm{NO}_{3} / \mathrm{dm}^{3}$ ), phosphates (from 0.02 to $0.03 \mathrm{mg} \mathrm{PO} / \mathrm{dm}^{3}$ ) and ammonia (from 0.03 to $0.1 \mathrm{mg} \mathrm{NH}_{4} / \mathrm{dm}^{3}$ ). Small increases in indices of salinity, such as the content of sulfates (from 102.39 to $103.71 \mathrm{mg} \mathrm{SO}_{4} / \mathrm{dm}^{3}$ ) and chlorides (from 31.0 to $33.16 \mathrm{mg} \mathrm{Cl} / \mathrm{dm}^{3}$ ), were also noted (Figure 7).

Table 2. Chemical parameters of habitat of Potametum alpini Podbielkowski patches.

\begin{tabular}{|c|c|c|c|c|c|c|c|c|c|c|c|c|c|c|c|}
\hline \multirow{2}{*}{ Water } & \multicolumn{12}{|c|}{$\mathrm{mg} / \mathrm{dm}^{3}$} & \multicolumn{3}{|c|}{$\mathrm{mg} / \mathrm{dm}^{3}$} \\
\hline & $\mathrm{Na}$ & $\mathbf{K}$ & Mg & $\mathrm{Ca}$ & $\mathrm{Fe}$ & Mn & Al & $\mathrm{Zn}$ & $\mathrm{Cu}$ & $\mathrm{Cd}$ & $\mathbf{P b}$ & $\mathrm{Ni}$ & $\mathrm{SO}_{4}$ & $\mathrm{NO}_{3}$ & $\mathrm{NH}_{4}$ \\
\hline \multirow{2}{*}{$\begin{array}{c}\text { Spring } \\
\text { Outflow } \\
\text { zone }\end{array}$} & 8.01 & 1.24 & 19.41 & 93.85 & 0.02 & - & 0.25 & - & 0.02 & - & - & - & 102.71 & 34.48 & 0.10 \\
\hline & 8.33 & 1.11 & 17.63 & 92.29 & - & - & 0.10 & 0.57 & 3.42 & 0.29 & 0.29 & 0.57 & 102.39 & 34.11 & 0.03 \\
\hline \multirow{2}{*}{ Sediments } & \multicolumn{12}{|c|}{$\mathrm{mg} / \mathrm{kg}$} & \multicolumn{3}{|c|}{$\mathrm{mg} / \mathrm{dm}^{3}$} \\
\hline & $\mathrm{Na}$ & $\mathrm{K}$ & $\mathrm{Mg}$ & $\mathrm{Ca}$ & $\mathrm{Fe}$ & $\mathrm{Mn}$ & $\mathrm{Al}$ & $\mathrm{Zn}$ & $\mathrm{Cu}$ & $\mathrm{Cd}$ & $\mathrm{Pb}$ & $\mathrm{Ni}$ & $\mathrm{SO}_{4}$ & $\mathrm{NO}_{3}$ & $\mathrm{NH}_{4}$ \\
\hline \multirow{2}{*}{$\begin{array}{l}\text { Spring } \\
\text { Outflow } \\
\text { zone }\end{array}$} & 91.95 & 925.21 & 1130.00 & 44038.45 & 5843.50 & 292.02 & 3400.50 & 194.22 & 20.31 & 0.63 & 57.27 & 30.35 & - & - & - \\
\hline & 53.95 & 186.32 & 1016.00 & 2631.12 & 8286.00 & 248.70 & 2674.50 & 221.67 & 21.11 & 0.28 & 43.31 & 15.25 & - & - & - \\
\hline \multirow{2}{*}{$\begin{array}{c}\text { Plants of } \\
\text { Potametum } \\
\text { alpini }\end{array}$} & \multicolumn{12}{|c|}{$\mathrm{mg} / \mathrm{kg}$} & \multicolumn{3}{|c|}{$\mathrm{mg} / \mathrm{dm}^{3}$} \\
\hline & $\mathrm{Na}$ & K & $\mathrm{Mg}$ & $\mathrm{Ca}$ & $\mathrm{Fe}$ & Mn & $\mathrm{Al}$ & $\mathrm{Zn}$ & $\mathrm{Cu}$ & $\mathrm{Cd}$ & $\mathrm{Pb}$ & $\mathrm{Ni}$ & $\mathrm{SO}_{4}$ & $\mathrm{NO}_{3}$ & $\mathrm{NH}_{4}$ \\
\hline Spring & 17039.50 & 34803.85 & 3140.00 & 11724.65 & 1040.00 & 115.80 & 1700.00 & 622.40 & 40.50 & - & 64.40 & 37.00 & - & - & - \\
\hline
\end{tabular}




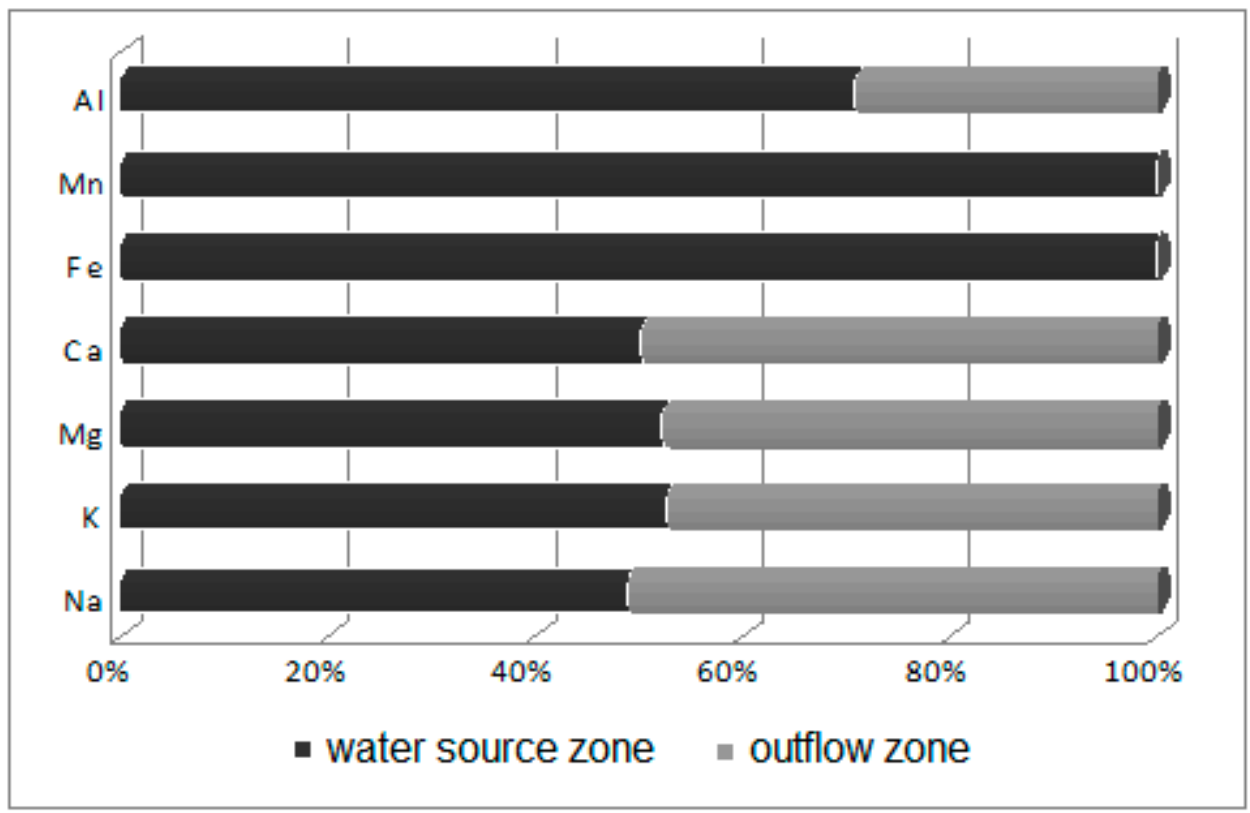

Figure 6. Ratio of water macroelement concentrations in the water source zone to those in the outflow zone.

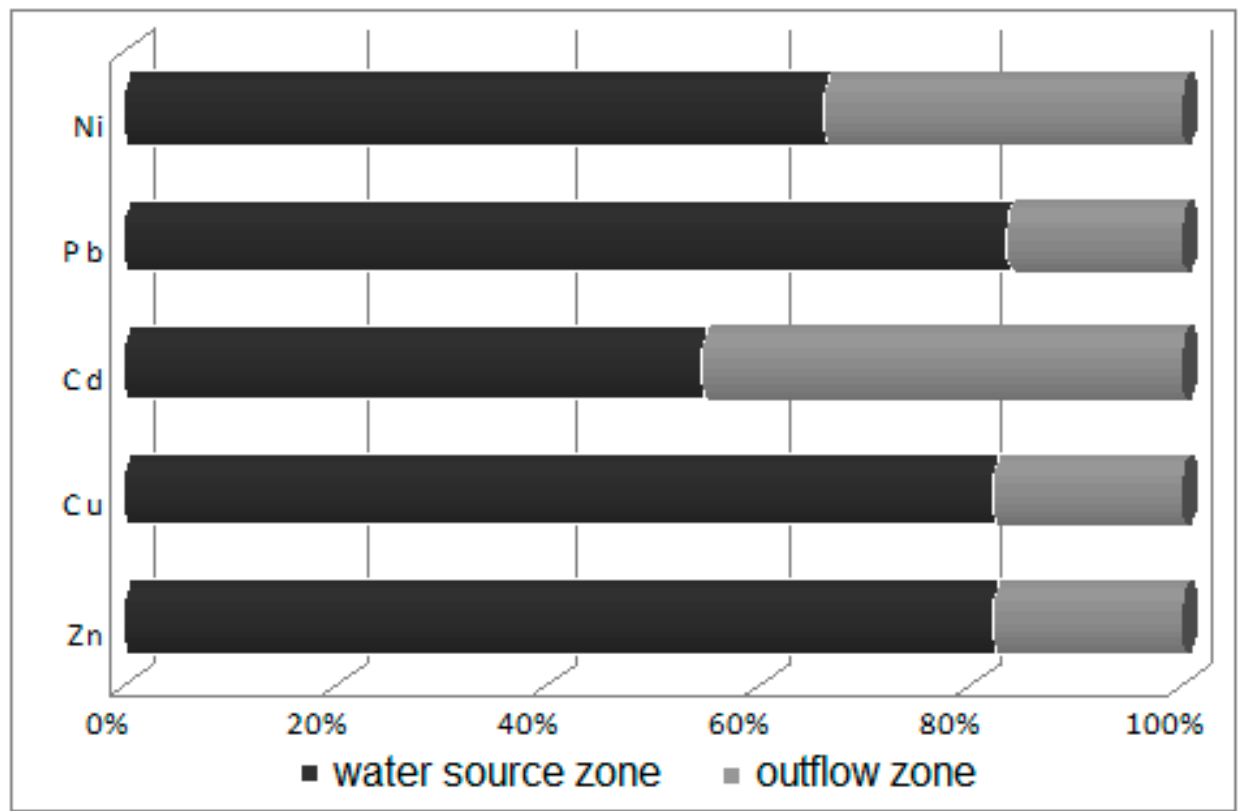

Figure 7. Ratio of water heavy metal concentrations in the water source zone to those in the outflow zone.

\section{Discussion}

The condition of the Potametum alpini patches found within the studied habitat may constitute evidence of the highly adaptive abilities of the plant species occurring there. This also confirms the effective adjustment of the plant community to natural conditions considered not very typical for it. As previously stated, patches of this association are noted to occur in various types of waters, including oxbow lakes, ponds, lakes and ditches [7-9]. The studied karst limnocrene spring is, however, quite different, i.e., not a eutrophic site. Moreover, our analyses (Table 2) showed that the water habitat of the limnocrene spring undergoes relatively small changes in its main physical and chemical parameters, with the concentrations of $\mathrm{Cl}, \mathrm{Mg}$ and $\mathrm{Ca}$ in the same range of values as those recorded in earlier 
studies at the same site $[33,34]$. Na and $\mathrm{K}$ were characterized by slightly higher concentrations, with an increase at the level of $1 \%$ mval, but the greatest difference was recorded in the $\mathrm{SO}_{4}$ concentration of the tested water, which exhibited an increase of more than $20 \%$ mval (Table 2). It also seems that the physical properties of water, such as $\mathrm{pH}$ and temperature, which have remained constant at the site for more than 24 years [33,34], are important for the proper development of Potametum alpini patches (Table 1). Indeed, taking into account the condition of the plants within the patches analyzed, one can state that the physical-chemical parameters of the limnocrene karst spring are currently optimal for the development of the patches of Potametum alpini (confirmed in the phytosociological Table 1).

Ideally, it would also be desirable to compare the habitat parameters of the studied Potametum alpini patches (or even of the species of Potamogeton alpinus) with those found at other sites, to place the present work in a broader context. However, according to our knowledge, the habitat data presented here are the first published for this plant community and thus such a comparison is not currently possible.

The chemical properties of the water at the study site indicate that the patches of Potametum alpini require relatively high concentrations of nutrients (Table 2). This is also confirmed by the presence of $P$. alpini patches in other eutrophic habitats.

Based on the analysis of all available data, i.e., for both the studied limnocrene spring (a rare habitat) and those reported in earlier papers (concerning the occurrence of P. alpini in eutrophic waters, i.e., very common habitats), one can assume that the patches of the analyzed plant community seem to be sensitive to some hitherto unknown factors that limit their occurrence. As a consequence, the P. alpini association should be really recognized as endangered in Europe, with the locality of that in the limnocrene karst spring in Poland given special protection.

This study also confirms the importance of rare microhabitats for global biodiversity. Research examining the as yet unknown physical and chemical factors limiting the range and development of patches of different plant associations should be conducted intensively, because plant communities, including rare, endangered and protected examples, are an important element of biodiversity at both continental and local scales. Indeed, all the issues included in the present paper are relevant, given their pertinence to the conservation and management of inland waters.

Author Contributions: K.S., designed study, data curation, visualization; K.S. and J.P., methodology, analyzed data, drafted paper (original draft); J.P., drafted paper (review and editing), project administration, supervision.

Funding: This research received no external funding.

Conflicts of Interest: The authors declare no conflict of interest.

\section{References}

1. Spałek, K.; Horska-Schwarz, S. Veronico beccabungae-Callitrichetum stagnalis (Oberd. 1957) Müller 1962, a plant association new to Poland-Quality of habitat. Acta Soc. Bot. Pol. 2009, 78, 345-349. [CrossRef]

2. Spałek, K.; Proćków, J. Karst springs as habitats for rare and protected plant species: A new inland locality of a halophyte plant Batrachium baudotii (Ranunculaceae) in a karst spring in Central Europe. J. Cave Karst Stud. 2011, 73, 158-161. [CrossRef]

3. Spałek, K.; Proćków, J.; Staśko, S.; Horska-Schwarz, S. Preliminary study on the unusual properties in the habitat of Ranunculetum baudotii in Central Europe. Cent. Eur. J. Biol. 2011, 6, 632-638. [CrossRef]

4. Krebs, C.J. Ecology: The Experimental Analysis of Distribution and Abundance, 4th ed.; Harper-Collins College Publishers: New York, NY, USA, 1994.

5. Braun-Blanquet, J. Pflanzensoziologie. Grundzüge der Vegetationskunde, 3rd ed.; Springer: New York, NY, USA, 1964; ISBN-13: 978-3709181119.

6. Oberdorfer, E. Pflanzensoziologische Exkursionsflora, 7th ed.; Eugen Ulmer: Stuttgart, Germany, 1994.

7. Podbielkowski, Z. Zarastanie rowów melioracyjnych na torfowiskach okolic Warszawy. Monogr. Bot. 1967, 23, 1-171. [CrossRef]

8. Schubert, R.; Hilbig, W.; Klotz, S. Bestimmungsbuch der Pflanzengesellschaften Mittel- und Nordostdeutschlands; G. Fischer Verlag: Stuttgart, Germany, 1995. 
9. Passarge, H. Pflanzengesellschaften Nordostdeutschlands. I. Hydro- und Therophytosa; J. Cramer: Stuttgart, Germany, 1996.

10. Passarge, H. Mitteleuropäische Potamogetonetea II. Phytocoenologia 1994, 24, 337-363. [CrossRef]

11. Oberdorfer, E. (Ed.) Süddeutsche Pflanzengesellschaften. Teil I; G. Fischer Verlag: Stuttgart, Germany, 1977.

12. Tomaszewicz, H. Roślinność wodna i szuwarowa Polski (klasy: Lemnetea, Charetea, Potamogetonetea, Phragmitetea) wg stanu zbadania na rok 1975; Rozprawy Uniwersytetu Warszawskiego: Warszawa, Poland, 1979.

13. Schratt, L. Potametea. In Die Pflanzengesellschaften Österreichs. Teil II. Natürliche waldfreie Vegetation; Grabherr, G., Mucina, L., Eds.; G. Fischer Verlag: Stuttgart, Germany, 1993; pp. 53-78.

14. Matuszkiewicz, W. Przewodnik do oznaczania zbiorowisk roślinnych Polski; Wydawnictwo Naukowe PWN: Warszawa, Poland, 2005.

15. Hilbig, W. Übersicht über die Pflanzengesellschaften des südlichen Teiles der DDR. 1. Die Wasserpflanzengesellschaften. Hercynia NF 1971, 8, 4-33.

16. Ochyra, R. Roślinność lejków krasowych w okolicach Staszowa na Wyżynie Małopolskiej. Monogr. Bot. 1985, 66, 1-136. [CrossRef]

17. Pott, R. Die Pflanzengesellschaften Deutschlands, 2nd ed.; Verlag E. Ulmer: Stuttgart, Germany, 1995.

18. Černohous, F.; Husák, Š. Macrophyte Vegetation of Eastern and North-Eastern Bohemia. Folia Geobot. Phytotaxon. 1986, 21, 113-161. [CrossRef]

19. Julve, P. Synopsis phytosociologoque de la France (communautés de plantes vasculaires). Lejeunia 1993, 140, $1-160$.

20. Borhidi, A. Critical Revision of the Hungarian Plant Communities; Janus Pannonius University: Pécs, Hungary, 1996.

21. Borhidi, A. Magyarország Növénytársulásai; Akadémiai Kiadó: Budapest, Hungary, 2003.

22. Ninot, J.M.; Carreras, J.; Carrillo, E.; Vigo, J. Syntaxonomic conspectus of the vegetation of Catalonia and Andorra 1: Hygrophilous herbaceous communities. Acta Bot. Barc. 2000, 46, 191-237.

23. Rennwald, E. Rote Liste der Pflanzengesellschaften Deutschlands mit Anmerkungen zur Gefährdung. In Verzeichnis und Rote Liste der Pflanzengesellschaften Deutschlands; Rennwald, E., Ed.; Schr.-R.f. Vegetationskunde: Bonn-Bad Godesberg, Germany, 2000; Volume 35, pp. 393-592.

24. Lawesson, J.E. A tentative annotated checklist of Danish syntaxa. Folia Geobot. 2004, 39, 73-95. [CrossRef]

25. Paal, J.; Trei, T. Vegetation of Estonian watercourses; the drainage basin of the southern coast of the Gulf of Finland. Ann. Bot. Fenn. 2004, 41, 157-177.

26. Dubyna, D.V. Višča Vodna Roslynnist; Instytut Botaniki im. M.G. Holodnego NAN Ukraïny: Kyïv, Ukraine, 2006.

27. Redžić, S. Syntaxonomic diversity as an indicator of ecological diversity-Case study Vranica Mts in the Central Bosnia. Biologia 2007, 62, 173-184. [CrossRef]

28. Teteryuk, B.Y. Aquatic and helophyte vegetation of the Donty Lake (The Komi Republic). Veg. Russ. 2008, 12, 76-96.

29. Hrivnák, R.; Kochjarová, J.; Ot'ahel'ová, H. Vegetation of the aquatic and marshland habitats in the Orava region, including the first records of Potametum alpini, Potametum zizii and Ranunculo-Juncetum bulbosi in the territory of Slovakia. Biologia 2011, 66, 626-637. [CrossRef]

30. Šumberová, K. Potametea. In Vegetation of the Czech Republic. 3. Aquatic and Wetland Vegetation; Chytrý, M., Ed.; Academia: Praha, Czech Republic, 2011; pp. 100-247.

31. Borhidi, A.; Kevey, B.; Lendvai, G. Plant Communities of Hungary; Akadémiai Kiadó: Budapest, Hungary, 2012.

32. The Plant List. Available online: http://www.theplantlist.org/ (accessed on 1 January 2018).

33. Staśko, S. Hydrogeological description of some chosen springs of the Opole District. Mater. Stud. Opol. 1984, $26,277-298$.

34. Staśko, S. Wody podziemne w węglanowych utworach triasu opolskiego. Prace Geol. 1992, 32, 1-71.

(C) 2019 by the authors. Licensee MDPI, Basel, Switzerland. This article is an open access article distributed under the terms and conditions of the Creative Commons Attribution (CC BY) license (http://creativecommons.org/licenses/by/4.0/). 